\title{
HUBUNGAN PARITAS,USIA PERKAWINAN DENGAN RESIKO LESI PRAKANKER SERVIKS PADA PASANGAN USIA SUBUR DI KELURAHAN PETUK BUKIT
}

\author{
Sofia Mawaddah ${ }^{1)}$, Ivanna Dwi Susanti ${ }^{2)}$ \\ ${ }^{1,2)}$ Jurusan Kebidanan,Poltekkes Kemenkes Palangka Raya,Jln G.Obos,73112 \\ E-mail:sofizline@gmail.com
}

\begin{abstract}
Risk factors that support cervical cancer at the age of marriage, the younger the sexual intercourse the more risk of cervical cancer. Knowing the relationship between parity and age of marriage with the risk of cervical precancerous lesions in WUS. This studies using the Cross Sectional approach. This research was conducted in the Petuk Bukit Kelurahan with a sample of 35 respondents obtained by consecutive sampling method. Analysis used in this study was the Chi Square. The risk of cervical precancerous lesions in mothers married at age $\geq 20$ years with a positive IVA result was 10 respondents $(83.3 \%)$. And parity with the highest positive IVA results was mothers with multipara maternal parity of 19 respondents $(54.3 \%)$. The multiparous parity $\mathrm{p}$ value is $1,000(\alpha<0.05)$ and the grandemultiparous parity $p$-value is $0.093(\alpha<0,05)$, there is no relationship between parity and the risk of cervical precancerous lesions in mothers of fertile couples. The p-value of mother's age at marriage is $0.033(\alpha<0.05)$. There is a relationship between marital age and the risk of precancerous cervical lesions in mothers of fertile age couples
\end{abstract}

Keywords: IVA, marital age, precancerous cervical lesions

\begin{abstract}
Abstrak
Faktor risiko yang mendukung timbulnya kanker serviks pada usia menikah, aktif melakukan hubungan seksual dan berganti ganti pasangan juga merupakan faktor risiko terkena kanker serviks.Tujuan Penelitian hubungan antara paritas dan usia perkawinan dengan resiko lesi prakanker serviks pada WUS. Metode penelitian melalui pendekatan Cross Sectional. Penelitian ini dilakukan di Kelurahan Petuk Bukit dengan jumlah sampel 35 responden yang didapatkan dengan metode consecutive sampling. Analisa data yang digunakan yaitu Chi Square. Resiko lesi prakanker serviks pada ibu yang menikah pada usia $\geq 20$ tahun dengan hasil IVA positif yaitu sebanyak 10 responden $(83,3 \%)$. Dan paritas yang hasil IVA positif tertinggi yaitu ibu dengan paritas ibu multipara 19 responden $(54,3 \%)$. Nilai $p$-Value paritas multipara yaitu $1,000(\alpha<0,05)$ ,Nilai $p$-Value paritas grandemultipara yaitu $0,093(\alpha<0,05)$ tidak ada hubungan antara paritas dengan resiko lesi prakanker serviks pada ibu pasangan usia subur. Nilai $p$-Value usia ibu saat menikah yaitu $0,033(\alpha<0,05)$. Hal ini menunjukan bahwa ada hubungan antara usia perkawinan dengan resiko lesi prakanker serviks pada ibu pasangan usia subur.
\end{abstract}

Kata Kunci: IVA, usia perkawinan, lesi prakanker serviks

\section{PENDAHULUAN}

Kanker serviks adalah penyakit tumor ganas pada daerah mulut rahim sebagai akibat adanya pertumbuhan jaringan yang tidak terkontrol dan merusak jaringan normal disekitarnya. 
Serviks atau leher rahim merupakan bagian ujung bawah rahim yangmenonjol ke liang senggama (vagina). Kanker serviks berkembang secara bertahaptetapi progresif. Proses terjadinya kanker ini dimulai dengan sel yang mengalamimutasi lalu berkembang menjadi sel displastik sehingga terjadi kelainan epitel yangdisebut displasia.

Penyakit kanker merupakan penyebab kematian terbanyak di dunia, dimana kanker sebagai penyebab kematian nomor 2 didunia sebesar $13 \%$ setelah penyakit kardiovaskuler. Setiap tahun, 12 juta orang di dunia menderita kanker dan 7,6 juta diantaranya meninggal dunia (WHO, 2015). Kejadian kanker dalam dua dekade mendatang akan mengalami kenaikan sebesar 50\%. Diketahui pada tahun 2015 jumlah penderita kanker mencapai 10 juta kasus, namun kasus kanker tersebut diperkirakan akan meningkat mencapai 15 juta pada tahun 2020 (Hartanti, 2015).
Sedangkan menurut data Riset Kesehatan Dasar tahun 2015, menunjukkan bahwa prevalensi tumor/kanker di Indonesia adalah 1,4 per 1000 penduduk. Prevalensi tumor/kanker umumnya lebih tinggi pada perempuan. Di Indonesia cakupan deteksi Dini kanker serviks masih rendah, yaitu sebesar $2,45 \%$ sehingga memerlukan upaya lebih kuat untuk mencapai target deteksi dini terhadap $50 \%$ perempuan usia 30 -50 tahun selama 5 tahun (Kemenkes RI, 2014).

Faktor risiko yang mendukung timbulnya kanker serviks pada usia menikah, semakin muda melakukan hubungan seksual semakin berisiko terkena kanker serviks. Perempuan aktif melakukan hubungan seksual juga merupakan faktor risiko terkena kanker serviks. Sering berganti ganti pasangan seksual dapat meningkatkan risiko untuk terjadinya kanker serviks. Paritas, yaitu pada ibu yang sering melahirkan anak, semakin banyak anak yang dilahirkan semakin 
tinggi risiko terjadi kanker serviks. Kebiasaan merokok juga diketahui meningkatkan risiko kanker serviks akibat dari paparan asap rokok yang diterima. Pernah menderita penyakit menular seksual dapat memudahkan penularan HPV (Rasjidi, 2017).

Lesi prakanker serviks yang sangat dini dikenal dengan Neoplasia Intraepitelial Serviks (NIS) atau Cervical Intraepithelial Neoplasia (CIN) ditandai dengan adanya perubahan displastik epitel serviks. Terminologi dari lesi preinvasif serviks telah mengalami perubahan (Mustika, 2017).

Salah satu alat skrining adanya kanker serviks adalah dengan metode inspeksi visual asetat (IVA). Pemeriksaan IVA merupakan test yang sederhana, efektif, tidak mahal dan dapat dilakukan oleh tenaga kesehatan selain dokter ginekologi. Hasil pemeriksaan IVA dengan hasil positif diduga sebagai lesi prakanker servik. Di Kelurahan Petuk Bukit banyak pernikahan pada usia dini dan ibu yang mempunyai anak lebih dari 2 anak. Sehingga, peneliti tertarik untuk meneliti tentang hubungan paritas dan usia perkawinan dengan resiko lesi prakanker serviks pada wus.

\section{METODE PENELITIAN}

Desain penelitian ini adalah analitik dengan study korelasi melalui pendekatan cross sectional. Populasi pada penelitian ini yaitu ibu pasangan usia subur di wilayah Kelurahan Petuk Bukit pada bulan Maret-Mei 2019 dengan jumlah sampel 35 responden yang dipilih menggunakan teknik pengembalian sampel Consecutive Sampling. Teknik pengumpulan data yaitu wawancara, observasi, sebelum melakukan semua prosedur penelitian terlebih dahulu peneliti melakukan informed consent dengan responden, menjelaskan kepada responden bagaimana prosedur penelitian dari awal pengambilan data sampai selesai. Jika responden tidak keberatan menjadi responden penelitian dan bersedia, peneliti meminta untuk responden mentandatangani 
lembar persetujuan menjadi responden penelitian. Lalu, melakukan pengisian Formulir Register Deteksi Dini Kanker Leher Rahim, Formulir Register IVA Positif Deteksi Dini Kanker Leher Rahim, diskusi terfokus FGD (Focus Grup Discussion) melalui penyuluhan dan kunjungan rumah.

Pada penelitian ini variabel bebas yaitu paritas dan usia perkawinan dan variabel terikat yaitu resiko lesi prakanker. Analisis dalam penelitian ini yaitu analisis univariat mengetahui

distribusi, frekuensi dan persentase dari karakteristik responden yaitu dari variabel paritas, usia perkawinan, lama pemakaian kontrasepsi hormonal, riwayat perkawinan dan riwayat keluarga yang menderita kanker serviks. Sementara, untuk menentukan hubungan antara variabel independen dengan variabel dependen dilakukan dengan uji statistik Chi Square dengan derajat yang $\sum$ dipakai adalah $95 \%$ dengan ketentuan probabilitas ( $p$ value $>0,05)$

HASIL DAN PEMBAHASAN

Tabel 1. Distribusi Frekuensi Karakteristik

\begin{tabular}{lcc}
\hline \multicolumn{1}{c}{ Karateristik Responden } & Frekuensi (f) & Persentase (\%) \\
\hline Usia & 1 & 2,9 \\
$\leq 20$ Tahun & 21 & 60,0 \\
20-30 Tahun & 13 & 37,1 \\
$\geq 30$ Tahun & 35 & 100 \\
\hline Total & & \\
\hline Pendidikan & 17 & 48,6 \\
SD & 13 & 37,1 \\
SMP & 5 & 14,3 \\
SMA & 35 & 100 \\
\hline Total & & \\
\hline Paritas & 11 & 31,4 \\
Primipara & 19 & 54,3 \\
Multipara & 5 & 14,3 \\
Grandemultipara & 35 & 100 \\
\hline Total & & \\
\hline Pemakaian KB Hormonal & 26 & 74,3 \\
$\leq 5$ Tahun & 9 & 25,7 \\
$\geq 5$ Tahun & 35 & 100 \\
\hline Total & & \\
\hline Riwayat Perkawinan & 28 & 80,0 \\
1 Kali Perkawinan & 7 & 20,0 \\
$\geq 1$ Kali Perkawinan & 35 & 100 \\
\hline Total & & \\
& &
\end{tabular}




\begin{tabular}{lcc}
\hline Riwayat Penyakit Keluarga & & \\
Ada & 0 & 0,0 \\
Tidak Ada & 35 & 100 \\
\hline Total & 35 & 100 \\
\hline Usia Perkawinan & & \\
$\leq 20$ Tahun & 23 & 65,7 \\
$\geq 20$ Tahun & 12 & 34,3 \\
\hline Total & 35 & 100 \\
\hline Lesi Prakanker Serviks & & \\
IVA Negatif & 16 & 45,7 \\
IVA Positif & 19 & 54,3 \\
Total & 35 & 100 \\
\hline
\end{tabular}

Tabel 2. Hubungan Paritas dengan Resiko Lesi Prakanker Serviks Pada Ibu PUS

\begin{tabular}{|c|c|c|c|c|c|c|c|c|}
\hline \multirow{3}{*}{$\begin{array}{l}\text { Karakteristik } \\
\text { Responden }\end{array}$} & \multicolumn{4}{|c|}{ Lesi Prakanker Serviks } & & & \multirow{3}{*}{$p$-Value } & \multirow{3}{*}{$\begin{array}{l}\text { OR } \\
(\mathrm{CI}: 95 \%)\end{array}$} \\
\hline & \multirow{2}{*}{\multicolumn{2}{|c|}{$\begin{array}{l}\text { IVA } \\
\text { Negatif }\end{array}$}} & \multirow{2}{*}{\multicolumn{2}{|c|}{$\begin{array}{l}\text { IVA } \\
\text { Positif }\end{array}$}} & \multirow{2}{*}{\multicolumn{2}{|c|}{ Jumlah }} & & \\
\hline & & & & & & & & \\
\hline \multicolumn{9}{|l|}{ Paritas } \\
\hline Primipara & 6 & 54,5 & 5 & 45,5 & 11 & 100 & & \multirow{4}{*}{$\begin{array}{l}1,080(0,24 \\
3-4,791) \\
0,455(0,23 \\
8-0,868)\end{array}$} \\
\hline Multipara & 10 & 52,6 & 9 & 47,4 & 19 & 100 & 1,000 & \\
\hline Grandemultipara & 0 & 0,0 & 5 & 100 & 5 & 100 & \multirow[t]{2}{*}{0,093} & \\
\hline Total & 16 & 45,7 & 19 & 54,3 & 35 & 100 & & \\
\hline \multicolumn{9}{|c|}{$\frac{\text { Tabel 3. Hubungan Usia Perkawinan dengan Resiko Lesi Prakanker Serviks Pada Ibu PUS }}{\text { Lesi Prakanker Serviks }}$} \\
\hline \multirow[t]{2}{*}{$\begin{array}{l}\text { Karakteristik } \\
\text { Responden }\end{array}$} & \multicolumn{2}{|c|}{$\begin{array}{l}\text { IVA } \\
\text { Negatif }\end{array}$} & \multicolumn{2}{|c|}{ IVA Positif } & \multicolumn{2}{|c|}{ Jumlah } & \multirow[t]{2}{*}{$p$-value } & \multirow[t]{2}{*}{$\begin{array}{c}\text { OR } \\
(\mathrm{CI}: 95 \%)\end{array}$} \\
\hline & $\mathrm{n}$ & $\%$ & $\mathrm{n}$ & $\%$ & $\mathrm{n}$ & $\%$ & & \\
\hline \multicolumn{9}{|l|}{ Usia Perkawinan } \\
\hline $\begin{array}{l}\geq 20 \text { Tahun } \\
\leq 20 \text { Tahun }\end{array}$ & $\begin{array}{c}2 \\
14\end{array}$ & $\begin{array}{l}16,7 \\
60,9\end{array}$ & $\begin{array}{c}10 \\
9\end{array}$ & $\begin{array}{l}83,3 \\
12,5\end{array}$ & $\begin{array}{l}12 \\
23\end{array}$ & $\begin{array}{l}100 \\
100\end{array}$ & \multirow{2}{*}{0,033} & $\begin{array}{r}0,129 \\
0.023-\end{array}$ \\
\hline Total & 16 & 45,7 & 19 & 54,3 & 35 & 100 & & $0,728)$ \\
\hline
\end{tabular}

\section{PEMBAHASAN}

Pada penelitian ini ibu yang menjadi responden pada usia ibu tertinggi rentang usia ibu 20-30 tahun yaitu sebanyak 21 responden $(60,0 \%)$, usia $\geq 30$ tahun yaitu sebanyak 13 responden $(37,1 \%)$ dan terendah $\leq 20$ tahun yaitu sebanyak 1 responden (2,9\%), untuk ibu dengan status pendidikan tertinggi pada tingkat SD yaitu 
sebanyak 17 responden (48,6\%), pada tingkat SMP yaitu sebanyak 13 responden $(37,1 \%)$ dan terendah pada tingkat SMA yaitu sebanyak 05 responden $(14,3 \%)$.

Paritas tertinggi pada multipara yaitu sebanyak 19 responden $(54,3 \%)$, primipara yaitu sebanyak 11 responden $(31,4 \%)$ dan terendah grandemultipara yaitu sebanyak 5 responden (14,3\%), untuk ibu dengan status usia perkawinan pertama kali tertinggi pada $\leq 20$ tahun yaitu sebanyak 23 responden $(65,7 \%)$ dan terendah usia perkawinan pertama kali $\geq 20$ tahun yaitu 12 responden (34,3\%), untuk ibu dengan status lama pemakaian kontrasepsi hormonal tertinggi pada $\leq 5$ tahun yaitu sebanyak 26 responden (74,3\%) dan terendah pada lama pemakaian kontrasepsi hormonal $\geq 5$ tahun yaitu sebanyak 09 responden $(25,7 \%)$.

Riwayat perkawinan tertinggi dengan status 1 kali perkawinan sah yaitu sebanyak 28 responden $(80,0 \%)$ dan riwayat perkawinan terendah dengan status $\geq 1$ kali perkawinan sah yaitu sebanyak 7 responden (20,0\%), tidak ada riwayat keluarga yang menderita kanker serviks (100\%) dan pemeriksaan lesi prakanker serviks tertinggi dengan hasil IVA positif yaitu sebanyak 19 responden $(54,3 \%)$ dan terendah pada pemeriksaan IVA negatif yaitu sebanyak 16 responden $(45,7 \%)$.

Berdasarkan hasil penelitian pada kelompok paritas dengan multipara lebih banyak sebesar 9 responden $(47,4 \%)$ daripada grandemultipara dengan resiko lesi pra kanker serviks dengan jumlah 5 (10\%) responden. Berdasarkan hasil uji analisis data dengan uji Chi-Square, paritas terhadap lesi prakanker serviks dibagi menjadi 2 dengan pembanding yaitu kategori primipara, diantaranya: Paritas pada ibu dengan kategori multipara didapatkan $p$-value sebesar 1,000 > 0,05 . Kemudian dari hasil analisis diperoleh $\mathrm{OR}=1,080$ artinya $\mathrm{ibu}$ dengan multipara mempunyai risiko 1,080 kali mengalami lesi prakanker serviks dibandingkan ibu PUS dengan primipara. Sedangkan, Paritas pada ibu dengan kategori grandemultipara didapatkan $p$ value $=0,093>0,05$ atau $(\alpha<0,05)$. Kemudian dari hasil analisis 
diperoleh $\mathrm{OR}=0,455$ artinya $\mathrm{ibu}$ dengan grandemultipara mempunyai risiko 0,455 kali mengalami lesi prakanker serviks dibandingkan ibu dengan primipara. Hal ini menunjukan bahwa tidak ada hubungan antara paritas dengan resiko lesi prakanker serviks pada ibu pasangan usia subur di Kelurahan Petuk Bukit.

Hasil penelitian ini tidak sejalan dengan hasil penelitian Wahyuningsih (2016) menunjukan bahwa sebagian besar responden yang memiliki paritas $>3$ kali lebih beresiko untuk mengalami lesi prakanker serviks dibanding dengan responden yang memiliki paritas <3 kali. Paritas adalah kemampuan wanita untuk melahirkan secara normal. Pada prosespersalinan normal, bayi bergerak melalui mulut rahim dan ada 2 kemungkinan sedikit merusak jaringan epitel ini berkembang kearah pertumbuhan sel abnormal yang berpotensi ganas. Jika jumlah anak yang dilahirkan melalui jalan nornal selain terjadinya robekan selaput serviks, dapat menyebabkan terjadinya perubahan sel abnormal.
Sehingga mempunyai kesempatan untuk terkontaminasi oleh virus yang menyebabkan infeksi. Bakteri tersebut ada karena kondisi hygiene vagina yang tidak terawat sehingga dapat berkembang menjadi keganasan. Paritas yang berbahaya adalah memiliki jumlah anak lebih dari 4 orang atau jarak persalinan terlampau dekat. Sebab dapat menyebabkan timbulnya perubahan sel - sel abnormal pada mulut rahim.

Berdasarkan penelitian yang dilakukan oleh Hidayat pada tahun 2015, menyimpulkan bahwa banyaknya anak yang dilahirkan berpengaruh dalam timbulnya penyakit kanker serviks. Paritas merupakan salah satu faktor risiko terjadinya kanker serviks dengan besar risiko 4,55 kali untuk terkena kanker serviks pada wanita dengan paritas $\geq 3$ dibandingkan wanita dengan paritas 3. Wanita yang memiliki 7 atau lebih kehamilan aterm mungkin memiliki peningkatan risiko kanker serviks (National Cancer Institute, 2014).

$$
\text { Selain itu, juga }
$$
mengungkapkan bahwa perlukaan pasca persalinan menjadikan awal 
terjadinya kanker servik apabila tidak segera ditangani. Bukan hanya perlukaan pasca persalinan yang menyebabkan terjadinya kanker serviks tetapi jarak persalinan yang terlalu dekat juga dapat menyebabkan terjadinya kanker serviks. Perlukaan setelah melahirkan dan jarak persalinan yang terlalu dekat akan menyebabkan virus penyebab kanker serviks masuk (Tapan, 2016).

Berdasarkan hasil uji analisa data dengan uji Chi-Square, usia perkawinan pertama kali terhadap resiko lesi prakanker serviks pada ibu yang menikah pada usia perkawinan $\geq 20$ tahun dengan hasil IVA positif yaitu sebanyak 10 orang $(83,3 \%)$ dan resiko lesi prakanker serviks pada ibu yang menikah pada usia $\leq 20$ tahun dengan hasil IVA positif yaitu sebanyak 9 orang $(12,5 \%)$.

Didapatkan $p$-value sebesar 0,033 dan nilai $\mathrm{OR}=0,129$ artinya ibu yang menikah pada usia $\geq 20$ tahun mempunyai risiko 0,129 kali mengalami lesi prakanker serviks dibandingkan ibu yang menikah pada usia $\leq 20$ tahun. Hal ini menunjukan bahwa ada hubungan antara usia perkawinan dengan resiko lesi prakanker serviks pada ibu pasangan usia subur di Kelurahan Petuk Bukit.

Sesuai dengan etiologi infeksinya, wanita yang memulai hubungan seksual pada usia muda akan meningkatkan risiko terkena kanker serviks karena sel kolumnar serviks lebih peka terhadap metaplasia selama usia dewasa maka wanita yang berhubungan seksual sebelum usia 18 tahun akan berisiko terkena kanker serviks lima kali lipat (Rasjidi, 2016).

Usia pertama kali melakukan hubungan seks merupakan salah satu faktor risiko terpenting karena penelitian para pakar menunjukkan bahwa semakin muda wanita melakukan hubungan seksual maka semakin besar risiko terkena kanker serviks. Wanita yang melakukan hubungan seks pertama sekali pada usia kurang dari 20 tahun mempunyai risiko 3 kali lebih besar daripada wanita yang berhubungan seksual pertama sekali pada usia lebih dari 20 tahun. Umumnya selsel mukosa baru matang setelah wanita berusia 20 tahun ke atas. 
Jadi, seorang wanita yang menjalin hubungan seks pada usia remaja, paling rawan bila dilakukan di bawah usia 16 tahun (Kartika,2016).

Hal ini berkaitan dengan kematangan sel-sel mukosa pada serviks. Pada usia muda, sel-sel mukosa pada serviks belum matang. Artinya, masih rentan terhadap rangsangan. Sehingga tidak siap menerima rangsangan dari luar. Termasuk zat-zat kimia yang dibawa sperma. Karena masih rentan, sel-sel mukosa bisa berubah sifat menjadi kanker. Sifat sel kanker selalu berubah setiap saat yaitu mati dan tumbuh lagi. Dengan adanya rangsangan, sel bisa tumbuh lebih banyak dari sel yang mati, sehingga perubahannya tidak seimbang lagi. Kelebihan sel ini akhirnya bisa berubah sifat menjadi sel kanker. Lain halnya bila hubungan seks dilakukan pada usia di atas 20 tahun, dimana sel-sel mukosa tidak lagi terlalu rentan terhadap perubahan (Anolis,2017)

Berdasarkan penelitian ini menunjukan bahwa dari 35 responden sebesar 19 responden $(54,7 \%)$ IVA positif, dilakukan test
IVA karena responden sudah aktif melakukan hubungan seksual. IVA adalah pemeriksaan skrining kanker serviks dengan inspeksi visual pada serviks dengan cara pemberian asam asetat. Setelah dilihat posisinya, leher rahim dipulas dengan asam asetat 3-5\%, selama 1 menit. Pemberian ini tidak menyakitkan dan hasilnya langsung saat itu juga dapat disimpulkan normal (negatif), positif (ada lesi pra-kanker). Asam asetat atau dikenal dengan asam cuka berguna mendeteksi dini kanker serviks secara mudah dan murah. Metode ini sudah dikenalkan sejak 1925 oleh Hans Hinselman dari Jerman, tetapi baru diterapkan sekitar tahun 2005.

Cara ini selain mudah dan murah, juga memiliki keakuratan sangat tinggi dalam mendeteksi lesi atau pra kanker, yaitu mencapai 90\%. Deteksi dini ini tidak harus dilakukan oleh dokter, tetapi bisa dipraktikan oleh tenaga terlatih seperti bidan dipuskesmas. Dalam waktu sekitar 60 detik sudah dapat dilihat jika ada kelainan, yaitu munculnya plak putih pada serviks. Plak putih ini bisa diwaspadai 
sebagai luka prakanker. tes skrining dapat membantu mencegah terjadinya kanker serviks dan bertujuan untuk mendeteksi lebih dini terjadinya kanker serviks (Daniel Danny Khusen, 2017).

\section{SIMPULAN}

Kanker serviks dapat disebabkan oleh berbagai perilaku penderita itu sendiri diantaranya adalah hubungan seksual yang dilakukan pada usia muda yaitu kurang dari 20 tahun, berganti ganti pasangan seksual lebih dari satu, memiliki banyak anak(lebih dari lima orang), personal hygiene yang buruk, daya tahan tubuh yang lemah, dan kurangnya pengetahuan tentang Test IVA / pap smear secara rutin pada wanita yang telah aktif melakukan hubungan seksual.

\section{UCAPAN TERIMA KASIH}

Peneliti sangat berterima
kasih kepada Kelurahan Petuk
Bukit yang sudah bersedia
memfasilitasi peneliti dari awal
proses penelitian sampai akhir
penelitian dan kepada ibu-ibu yang
bersedia menjadi responden dalam
penelitian ini.

\section{DAFTAR PUSTAKA}

A.A.Gde Raka Arista Mas Putra. (2016). Hubungan Paritas dan Usia Perkawinan Sebagai Faktor Risiko Lesi Prakanker Serviks Pada Ibu Pasangan Usia Subur Di Wilayah Kerja Puskesmas Sukasada II. Jurnal Kesehatan Tasikmalaya.

Badan Penelitian Dan Pengembangan

Kesehatan Kementerian Kesehatan $R I$, 2015. (2014). Jakarta: Riset Kesehatan Dasar.

Buku Aplikasi Asuhan Keperawatan Berdasarkan Diagnosis Medis dan Nanda (North Amercan Nursing Association). (2015).

Buku Panduan Pelaksanaan Kanker Serviks, Komite Penanggulangan Kanker Nasional Kementerian Kesehatan RI, 2015

Desen,Willie, J. (2017). Buku Ajar Onkologi Klinis. Jakarta: Badan Penerbit FKUI.

Duwi Basuki, Ayu Agustina Puspitasari."Hasil Skrining Metode Pemeriksaan Inspeksi Visual Asam Asetat (IVA) Pada Wanita Usia Subur Di Puskesmas

Blooto".Publikasi.Jurnal

Khatulistiwa;Universitas

Muhammadiyah.

Handayani, I. F., 2016. Perbandingan 
Karakteristik dan Pengetahuan tentang Kanker Servik Pada Wanita Dengan Inspeksi Visual Asam Asetat (IVA) Positif di Pesisir dan

Perkotaan.Publikasi.Jurnal

Kesehatan;Stikes

Mabaul

Yogyakarta.

Hartanti, N.2015.Cegah dan Deteksi Kanker Serviks, Jakarta:PT.Elek Media

Kartikawati Erni, 2017.Bahaya Kanker Payudara \& Kanker Serviks.Bandung:Buku Baru.

Notoatmojo, Soekidjo.2015.Metode Penelitian Kesehatan.Jakarta: Rineka Cipta.

Nurul, Febriana.2015.Analisis Manajemen Pelayanan Tes IVA (Inspeksi Visual Asam Asetat) di Puskesmas Gunungpati.Jurnal Forum Kesehatan;Poltekkes Solo Nurwijaya, Hartati, Andrijono, H.K. Suheini.2010.Cegah dan Deteksi Kanker Serviks. Jakarta:Elek Media Komputindo.

Umri, S.'Hubungan Usia Pertama Kali Melakukan Hubungan Seks Dengan Kejadian Kanker Serviks di Rumah Sakit Pusat Haji Adam Malik Medan”.Jurnal Info Kesehatan;Kupang
Rasjidi, I., 2016 .Manual Prakanker Serviks, Edisi I.Jakarta;Sagong Seto.

Riset Kesehatan Dasar, Jakarta 01 Desember 2014. RIKESDAS. Badan Litbang Kemenkes Republik Indonesia: Jakarta.

WHO, 2015. Estimated Cervical Cancer Incidence Wordwide in 2012. Word Health Organization, Geneva. 